\title{
The Role of Perceived Stress as a Moderator on the Relationship between Organizational Trust and Work Engagement in Palestinian Ministries: An Empirical Approach
}

\author{
Tariq T. Jarrar (corresponding author) \\ School of Management \\ Universiti Sains Malaysia (USM) \\ Penang - Malaysia \\ E-mail: tariq.jarrar@gmail.com \\ Dr. Hazril Izwar Ibrahim \\ School of Management \\ Universiti Sains Malaysia (USM) \\ Penang - Malaysia \\ E-mail: hazrilizwar@usm.my
}

Received: Feb. 1, 2021 Accepted: Feb. 25, 2021 Online published: Mar. 25, 2021

doi:10.5296/ijhrs.v11i2.18286 URL: https://doi.org/10.5296/ijhrs.v11i2.18286

\begin{abstract}
The purpose of this paper is to employ Social Exchange Theory to examine the relationship between organizational trust and work engagement and the role of perceived stress as a moderator in Palestinian ministries. For this purpose, the study utilizes a sample of 178 respondents of executive-level employees in which primary data collection is conducted using survey instrument and PLS-SEM for data analysis. The study proposes that perceived stress moderates the impact of organizational trust on vigor, dedication and absorption, and that perceived stress plays an important role in moderating the relationship between organizational trust and employees' work engagement. The study concludes that implementation of organizational trust is important in Palestinian ministries to support
\end{abstract}


employees' engagement and to create positive outcome in the workplace.

Keywords: organizational trust, work engagement, perceived stress, social exchange theory, public sector

\section{Introduction}

Empirical studies examining organizational trust, perceived stress, and employee engagement in organizations and governmental ministries in developing countries, especially the Middle East are scant. In the context of Palestine, for example, few studies are available about employee engagement within the Middle East in general and Palestine in particular. The importance of organizational trust in the ministries in the West Bank in Palestine are centered on structure and climate; they affect employee performance and engagement because the way an employee views one's employer and work environment influences how one feels and behaves when working, which will be reflected in the performance of the organization.

Employee engagement became a very popular concept in organizational studies during the past twenty years. Engaged individuals in the workplace are recognized, in general, and easier to work with because they feel appreciated for their contributions to their organizations. They therefore disseminate a culture of employee engagement throughout their workplace. Ideally, engaged employees are acknowledged in the organizations and this leads to them being laden with more responsibilities that impact positively on their career path (Albrecht et al., 2015).

Organizations need employees who feel actively engaged with their work. Febriansyah, Pringgabayu, Hidayanti, and Citra Febrianti (2018) define an engaged employee as an individual who is completely involved in, and dedicated to, the workplace. Engagement is essentially defined as "an innate human desire to contribute something of value in work place". Work engagement is viewed as a significant construct because it has been associated with enhanced trust in organizations. It is important for the managers to know and ensure that his or her employee work outcomes achieve the particular work indicators in the workplace.

Work-derived stress, a universal phenomenon, impacts many workers in various work environments. Nowadays, employees with a hectic work schedule are likely to experience stress (Khoury \& Analoui, 2010b). Stress at work can affect a manager's physical and mental health, causing errors, reduced achievements, and dissatisfaction (Rhee, 2010).

The Palestinian political and economic situation, and its traditional culture, presents a unique framework for this exploratory research. Through the years, Palestinians have faced some dangerous difficulties due to the Israeli occupation, which has significantly affected Palestinian culture (Jouda et al., 2016). The economic and political facts which describe Palestinian culture have affected the organizational procedures of Palestinian organizations. Peace remains as elusive as ever, in spite of hope and effort. The conflict in Palestine has certainly contributed to both a large amount of uncertainty and work-related stress. According to Khoury \& Analoui (2010a), the military struggle and the persistent occupation have produced inveterate suffering of victims living in a tragedy. When discussing quantitative indicators that depict such suffering, it is essential to mention their unaccomplished aims and 
their uncertain future.

It therefore becomes vital to investigate the relationship between organizational trust and work engagement with the moderation effect of perceived stress in a Palestinian context. This study explores the positive or negative relationship between the organizational trust and work engagement in ministries in Palestine. The following section will discuss literature review, methodology, data analysis, results, discussion, limitation and conclusion.

\section{Literature Review}

There is no consensus among authors on a single definition for organizational trust. Organizational trust has long been perceived as a critical element in the perception of interpersonal dynamics, which is a key individual characteristic in organizational behavior(Rhee, 2010). Organizational trust is important in positive relationships between employees and organizations because without trust, the transaction costs of maintaining the relationship increases for individuals and organizations (Kramer \& Tyler, 1996). Indeed, researchers have found that organizational trust conflicts can lead to costly dysfunctional behavior in the workplace and a decline in positive organizational behaviors (Guinot et al., 2013). Furthermore, high standards of organizational trust in the workplace can lead to improved levels of organizational commitment.

Mayer, Davis, \& Schoorman (1995) define trust as the willingness of a party to be responsive to the activity of the other party based on the anticipation that the other party will reciprocate in an action beneficial to the trustor. While Hassan et al., (2012) propose that trust is a focal factor in increasing an organization's long-term prosperity and existence, this is especially pertinent today given the uncertainty and competitiveness existing within the current global work climate

It can be said that trust determines the degree of harmony and cooperation between people. Trust is the "emotion of believing and engaging without fear and hesitation" (Dunn \& Schweitzer, 2005). Trust entails neither side of a relationship is exploited, particularly with regards to perceived weaknesses (Duane \& O'Reilly, 2017), which entails expecting positive actions from other individuals (Jong\& Elfring, 2010). Put differently, trust is a human feeling reinforced and sustained by mutual consideration and commitment, and is a concept based on sincerity and integrity in the most general feeling (Gülbahar, 2017). Organizational trust is important for both supervisors and employees; moreover, trust forms the foundation of compatible and fruitful relationships and effective cooperation within the organization (Tschannen-Moran \& Hoy, 1998) in order to improve employee performance and increase the organization's level of effectiveness.

When a subordinate trusts the supervisor, work performance in organizational citizenship behavior will be achieved which will result in encouraging the subordinate to preserve the relationship, keeping abreast with the organization objective (Bharanitharan, Chen, Bahmannia, \& Lowe 2018) and making an additional effort to create value for the organization (Mayer \& Gavin, 2005). Moreover, when a trust-based environment is established and maintained, a subordinate's sense of duty and responsibility will be improved 
(Brower et al., 2009). Such trust also encourages subordinates' future anticipation of benevolence, resulting in extra motivation on their part (Ferrin \& Dirks, 2002). Conversely, subordinates without trust in their superior will not be encouraged to make any extra effort to carry or assume extra responsibility in an exceedingly structured environment (Pierce \& Gardner, 2004). As such, feelings of trust and mutual duties are key for developing social exchange; moreover, developing trust within organizations is a key component of improving social exchange relationships (Hsu et al., 2017). Social exchange relationships then require unspecified duties in which the parties involved swap effort toward one another, whereas economic exchanges underline the financial and tangible sides of exchange relationships.

Social exchange relationships entail unspecified obligations in which the parties involved reciprocate effort toward one another. As such, feelings of trust and mutual obligation are key for developing exchange. Accordingly, the importance of enhancing the role of organizational trust is to help maximizing achieving organizational goals and identifying the role of building relationship between organizational trust perceived stress, and work engagement in ministries in Palestine.

Although it is agreed that stress is a common phenomenon at the workplace, views differ on the significance of worker characteristics versus the working situation as its essential cause. The differing perspectives suggest various ways to prevent stress at work. Several individual characteristics, such as personality and coping skills, can be very significant predictors of whether particular job situations will result in stress (Bhui, Dinos, Galant-Miecznikowska, De Jongh, et al., 2016). In other words, what is considered stressful for one individual may have the opposite effect on another individual.

Stress occurs if there is a mismatch between the demands placed on a person and his or her ability to meet those demands. Incompatibility between the objective of the job environment and a person's particular perceptions of that environment can result in work stress. However, stress is not necessarily a negative event. There two main types of stress: good stress and bad stress (Guinot et al., 2014). In terms of good stress theory, work stress happens when employees' knowledge, skills, abilities, and attitudes are suited to or commensurate with their work demands in organizations. In this condition, it may boost the capacity of employees to manage their physiological and psychological stresses (Na'eim Ajis et al., 2009).

Perceived stress is the feelings or thoughts that an individual has about how much stress he or she is under at any given time (Lawless et al., 2015). Perceived stress incorporates concerns or fear regarding the uncertainty and unpredictability of an individual's life, how often the individual has to deal with conflicts, how much change is occurring in an individual's life, and trust in an individual's power to deal with problems or obstacles (Wiegner et al., 2015). It is not a measure of the types of stressful events which occurs to an individual but mostly how an individual feels about the common stressfulness of his life and his ability to handle such stress. Individuals may suffer comparable negative events but perceive the impact or gravity of these to different degrees as a result of factors such as personality, coping resources, and support. Consequently, perceived stress reflects the interaction between an individual and their environment (Wong et al., 2012). the individual's personality type 
In general, work stress is a sense of personal dysfunction that an employee experiences as a result of a perceived situation or events in the workplace; in other words, work stress is the psychological and physiological echo caused by a job status in which the worker feels uncomfortable and undesired (Chen et al., 2006). Perceived stress is a risk and can create mental and physical problems for an individual (Safadi et al., 2019). Since stress varies depending on the individual's personality type, some individuals are capable of managing and resolving stress, while others take this seriously and think everything is their responsibility. Therefore, stress can affect individuals differently depending on the coping mechanisms utilized by the individual. If handled properly, stress can be something that can be dealt with and will not result in any negative outcomes

Notwithstanding the presence of stress-related factors, Palestinian organizations are not fully aware of the significance of this issue and are thus left unattended. Since perceived stress is recognized as a social problem, stress management has become a significant and urgent need for many organizations (Khoury \& Analoui, 2010a). The discussions in this paper point to perceived stress as determining the relationship between the organizational trust and work engagement in the Palestinian ministries.

Work engagement is important because it gives employees the opportunity for involvement in the organization to utilize their experience, which helps the administration to determine key goals and objectives. According to Yener, Yaldıran, and Ergun (2012), work engagement is one of the most popular terms used in academia and business organizations. Engagement has been defined by Kahn (1990a) as employees working by expressing themselves physically, cognitively, and emotionally during work performances, while Vineburgh (2010) defines engagement as "a positive attitude held by employees toward the organization and its values." Schaufeli, Bakker, \& Salanova (2006) define work engagement as a positive and fulfilling disposition that helps employees work with vigor, dedication, and absorption.

According to Yener et al. (2012), the three dimensions of work engagement vigor, dedication, and absorption can be defined as follows: Vigor is the feeling of high energy and fitting with work even when facing obstacles. There are many antecedents for vigor. Kahn (1992) points to the relationship of the psychological meaningfulness that precedes vigor for work. Researchers also observed that individuals are willing to expend effort when work satisfies several personal needs. May, Gilson, \& Harter (2004) agree with Kahn (1992), suggesting that engagement occurs when employees are given the necessary facility, elements, and details to complete a task and when they feel a sense of merit.

Dedication refers to a powerful involvement which gives rise to positive feelings about work (Kular et al., 2008). Dedication is the result of individual consistency with the work and meaningful experiences gained while working. Dedicated employees have strong psychological attachment to their job tasks. They feel enthusiastic, even inspired, while working (Yener et al., 2012), and these experiences are transformed into a feeling of pride in their work. Thus, dedication describes the extent to which employees are involved in their work.

Absorption is a state of engrossment in work characterized by being fully concentrated and 


\section{Macrothink}

International Journal of Human Resource Studies

ISSN 2162-3058

2021, Vol. 11, No. 2

unaware of time, making it extremely difficult for the worker to detach one's self from work (Yener et al., 2012). In other words, absorption is the total immersion of an employee in work; it is marked by quick passage of time and difficulty in leaving work (Schaufeli et al., 2006).

According to Schaufeli et al., (2006) work engagement is defined as transient, positive, fulfilling, and work-related state of mind that fluctuates within individuals over a short period of time and is characterized by vigor, dedication, and absorption. This dynamic approach allows the researcher to study how leaders affect followers' work engagement in their natural work context through relationship between the employer and the employee, which is run by leaders. It comes as an outcome interaction between the environment and the individual, through the Social Exchange Theory and aligned with the argument between the organizational trust, perceived stress and work engagement. Hence, in this article, work engagement is a composite score that encompasses vigor, dedication, and absorption.

The hypotheses for this study are developed from the extensive literature review and the relationship between variables based on the proposed organizational trust, perceived stress, and work engagement. From the discussion above, the following hypotheses are formulated, see figure 1.

H1: There is a significant and positive relationship between Organizational Trust (OT) and Vigor.

H2: There is a significant and positive relationship between Organizational Trust (OT) and Dedication.

H3: There is a significant and positive relationship between Organizational Trust (OT) and Absorption.

H4: There is a significant and positive relationship Trust (OT) and Vigor: The Moderating Role of Perceived Stress.

H5: There is a significant and positive relationship between Organizational Trust (OT) and Dedication: The Moderating Role of Perceived Stress.

H6: There is a significant and positive relationship between Organizational Trust (OT) and Absorption: The Moderating Role of Perceived Stress. 


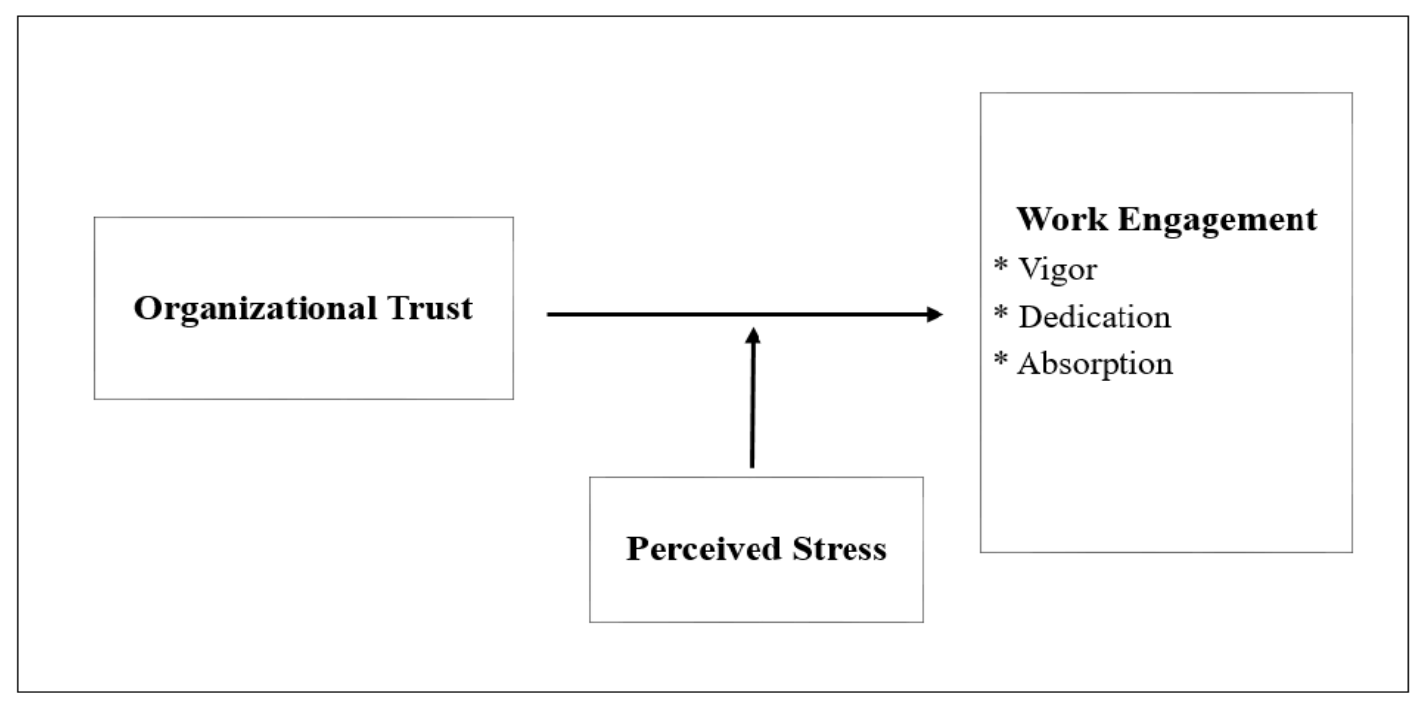

Figure 1. Conceptual Model and Hypotheses

\section{Method}

This study uses quantitative research methods; Data are collected from a sample of employees working in 21 ministries in Palestine. The inclusion criteria are the minimum qualification of a degree and a minimum work of one year in the respective ministry. The questionnaire used in this study is prepared used a Likert scale. A total of 200 responses (or $56 \%$ ) from 356 distributed questionnaire have been successfully collected via drop and collect method, with 178 being the minimum responses targeted based on G*Power, distributed with purposive sampling technique. Out of 200 total responses, 126 respondents $(63 \%)$ are males and remaining 74 respondents are females $(37 \%)$. These serve as the input to the analysis of the current study, which uses PLS-SEM method.

\section{Measures}

The questionnaire used in this study consists of five parts. The first part includes selection criteria of the ministry the participants are currently working in. The second part is the demographic profile of respondents: age, gender, marital status, level of education, length of service, and salary. The third part represents the organizational trust part that is measured with a scale from Mayer and Davis (1990). The scale is measured with a 5-point Likert scale with $1=$ strongly disagree and $5=$ strongly agree. The organizational trust subscale has 4 items. The fourth part is perceived stress that is measured using 10 items developed by Cohen (1983). Respondents are asked to indicate their agreement on a 5-point Likert scale: "1 = never, 5 = very often". The fifth part is work engagement that is measured with scale by 9-items employing the Utrecht Work Engagement Scale (UWES-9). There are three dimensions: vigor, dedication and absorption. The UWES-9 scale of measurement is based on Schaufeli et al. (2006) measurement on engagement. Respondents are asked to indicate their agreement on a 5-point Likert scale: "1 = strongly disagree, 5 = strongly agree".

Table 1 shows the demographic profile of the respondents. Means and standard deviation for 
all measures are shown in Table 2.

Table 1. Demographic Profile of the Respondents

\begin{tabular}{|c|c|c|c|}
\hline Profile & Description & Frequency & Percentage $(\%)$ \\
\hline \multirow[t]{6}{*}{ Age } & More than 20 - Less than 25 years old & 22 & 11 \\
\hline & More than 25 - Less than 30 years old & 37 & 18.5 \\
\hline & More than 30 - Less than 35 years old & 47 & 23.5 \\
\hline & More than 35 - Less than 40 years old & 49 & 24.5 \\
\hline & More than 40 - Less than 45 years old & 32 & 16 \\
\hline & More than 45 years old & 13 & 6.5 \\
\hline \multirow[t]{2}{*}{ Gender } & Male & 126 & 63 \\
\hline & Female & 74 & 37 \\
\hline \multirow[t]{2}{*}{ Marital } & Single & 62 & 31 \\
\hline & Married & 138 & 69 \\
\hline \multirow[t]{2}{*}{ Education } & Degree & 173 & 86.5 \\
\hline & Master & 27 & 13.5 \\
\hline \multirow[t]{4}{*}{ Experience } & More than 1 - Less than 5 years & 49 & 24.5 \\
\hline & More than 5 - Less than 10 years & 66 & 33 \\
\hline & More than $10-$ Less than 15 years & 53 & 26.5 \\
\hline & More than 15 years & 32 & 16 \\
\hline \multirow[t]{2}{*}{ Salary } & More than ILS 3000 - Less than ILS 5000 & 161 & 80.5 \\
\hline & More than ILS 5000 - Less than ILS 8000 & 39 & 19.5 \\
\hline
\end{tabular}

Table 2. Means and Standard Deviations

\begin{tabular}{|c|c|c|}
\hline Variable & Mean & Std. Deviation \\
\hline OT1 & 3.38 & 1.000 \\
\hline OT2 & 3.31 & .974 \\
\hline OT3 & 3.28 & .972 \\
\hline OT4 & 3.38 & 1.010 \\
\hline V1 & 3.27 & 1.000 \\
\hline V2 & 3.27 & .991 \\
\hline V3 & 3.21 & .999 \\
\hline D1 & 3.14 & .955 \\
\hline D2 & 3.14 & 1.003 \\
\hline
\end{tabular}




\begin{tabular}{lll} 
D3 & 3.08 & 1.048 \\
A1 & 3.32 & 1.026 \\
A2 & 3.27 & 1.025 \\
A3 & 3.32 & 1.001 \\
PS1 & 3.23 & 1.111 \\
PS2 & 3.09 & 1.195 \\
PS3 & 3.03 & 1.120 \\
PS4 & 3.20 & 1.164 \\
PS5 & 3.20 & 1.139 \\
PS6 & 3.08 & 1.067 \\
PS7 & 3.33 & .880 \\
PS8 & 3.29 & .876 \\
PS9 & 3.30 & .849 \\
PS10 & 3.02 & 1.175 \\
\hline
\end{tabular}

\section{Results}

Based on the mean score category described in Table 3, the mean scores of organizational ethical climate dimensions are regarded as low (Equal or less than 2.99) and moderate (3 to 3.99). The mean scores of organizational trust dimensions are regarded as moderate (3 to 3.99). Organizational trust 1 has a mean score of 3.38 ( $\mathrm{SD}=1.000)$, organizational trust 2 has a mean score of $3.31(\mathrm{SD}=0.974)$, organizational trust 3 has a mean score of $3.28(\mathrm{SD}=$ $0.972)$, organizational trust 4 has a mean score of $3.38(\mathrm{SD}=1.010)$.

The mean scores of work engagement are regarded as a moderate (3 to 3.99). Vigor 1 has a mean score of 3.27 ( $\mathrm{SD}=1.000)$; vigor 2 has a mean score of $3.27(\mathrm{SD}=0.991)$; vigor 3 has a mean score of $3.21(\mathrm{SD}=0.999)$. Dedication 1 has a mean score of $3.14(\mathrm{SD}=0.995)$; dedication 2 has a mean score of $3.14(\mathrm{SD}=1.003)$; dedication 3 has a mean score of 3.08 $(\mathrm{SD}=1.048)$. Absorption 1 has a mean score of $3.32(\mathrm{SD}=1.026)$; absorption 2 has a mean score of $3.27(\mathrm{SD}=1.025)$; absorption 3 has a mean score of $3.32(\mathrm{SD}=1.001)$.

As demonstrated in the measurement model, the $\mathrm{R} 2$ values for vigor, dedication and absorption are $0.193,0.203$ and 0.468 . The $\mathrm{R} 2$ values indicate that $19.3 \%, 20.3 \%$ and $46.8 \%$ of the variances in work engagement constructs (vigor, dedication and absorption) could be explained by organizational trust. Results from bootstrapping analysis suggest that of the three hypothesized paths tested, all point to positive effects on work engagement. Of these three dimensions, organizational trust has the strongest effect on absorption $(\mathrm{t}=18.487, \mathrm{p}<$ 0.01). Table 3 shows the detailed results of path coefficient, standard errors, and the t-values for the direct effects between organizational trust and work engagement (vigor, dedication and absorption). The PLS output is shown in Table 3. 
Table 3. Hypothesis Testing (Direct Effects between OT and WE)

\begin{tabular}{|c|c|c|c|c|c|c|c|}
\hline & & Original & Sample & Std. Dev. & T Statistics & $\mathrm{P}$ & \\
\hline \# & Path & Sample (O) & Mean $(\mathrm{M})$ & (STDEV) & (O/STDEV) & Values & Result \\
\hline \multirow{2}{*}{$\mathrm{H} 1$} & Organizational Trust -> & & & & & & \multirow{2}{*}{ Supported } \\
\hline & Vigor & 0.440 & 0.443 & 0.048 & 9.179 & 0.000 & \\
\hline \multirow{2}{*}{$\mathrm{H} 2$} & Organizational Trust -> & \multirow[b]{2}{*}{0.451} & \multirow[b]{2}{*}{0.454} & \multirow[b]{2}{*}{0.055} & \multirow[b]{2}{*}{8.128} & \multirow[b]{2}{*}{0.000} & \multirow{2}{*}{ Supported } \\
\hline & Dedication & & & & & & \\
\hline \multirow{2}{*}{$\mathrm{H} 3$} & Organizational Trust -> & \multirow[b]{2}{*}{0.684} & \multirow[b]{2}{*}{0.685} & \multirow[b]{2}{*}{0.037} & \multirow[b]{2}{*}{18.487} & \multirow[b]{2}{*}{0.000} & \\
\hline & Absorption & & & & & & Supported \\
\hline
\end{tabular}

The mean scores of perceived stress are regarded as a moderate (3 to 3.99). Perceived stress 1 has a mean score of $3.23(\mathrm{SD}=1.111)$; perceived stress 2 has a mean score of $3.09(\mathrm{SD}=$ 1.195); perceived stress 3 has a mean score of 3.03 ( $\mathrm{SD}=1.120)$; Perceived stress 4 has a mean score of $3.20(\mathrm{SD}=1.164)$; perceived stress 5 has a mean score of $3.20(\mathrm{SD}=1.139)$; perceived stress 6 has a mean score of $3.08(\mathrm{SD}=1.067)$; perceived stress 7 has a mean score of 3.33 ( $\mathrm{SD}=0.880)$; perceived stress 8 has a mean score of $3.29(\mathrm{SD}=0.876)$; perceived stress 9 has a mean score of $3.30(\mathrm{SD}=0.849)$; perceived stress 10 has a mean score of 3.02 $(\mathrm{SD}=1.175)$.

To examine the significance of interaction effect in explaining the variance on work engagement, the study employs the effect size (f2) as suggested by Henseler et al., (2009) It can be calculated by using Cohen's (1988) equation i.e., R2 included - R2 excluded / 1 - R2 included. The effect size value of $0.02,0.15$, and 0.35 are considered small, moderate, and large respectively (Cohen, 1998). In the current study, interaction effects $\times$ Perceived Stress are able to explain the small amount of variance in work engagement, which are also the statistically important supported hypothesis. The rest of interaction impacts, which are not statistically important, have an effect size that is below the threshold based on Cohen's (1998) rule of thumb (Table 4).

According to Chin et al. (2003) "small effect size (f2) does not necessary mean that the moderator effect is negligible, even small interaction effect can be meaningful, if the resulting beta changes are meaningful, then it is significant to take these condition in consideration". Therefore, hypotheses H4 and H6 are supported while hypothesis H5 is not supported. 
Table 4. Moderation Effect Results

\begin{tabular}{|c|c|c|c|c|c|c|c|}
\hline & & Original & Sample & Std. Dev. & T Statistics & $\mathrm{P}$ & \\
\hline$\#$ & Path & Sample (O) & Mean (M) & (STDEV) & (O/STDEV) & Values & Result \\
\hline $\mathrm{H} 4$ & OT $\times$ PS - Vigor & -0.111 & -0.109 & 0.057 & 1.954 & 0.025 & Supported \\
\hline \multirow[t]{3}{*}{ H5 } & OT×PS - Dedication & & & & & & Not \\
\hline & & 0.002 & 0.001 & 0.063 & 0.031 & 0.488 & \\
\hline & & & & & & & Supported \\
\hline H6 & OT×PS - Absorption & -0.123 & -0.123 & 0.036 & 3.374 & 0.000 & Supported \\
\hline
\end{tabular}

\section{Discussion}

The present study has 6 major hypotheses that measure the level of significance of direct relationship between the variables of organizational trust and work engagement. The results from the path coefficients attest that out of the 3 hypotheses, 3 are supported.

Hypotheses $\mathrm{H} 1, \mathrm{H} 2$ and $\mathrm{H} 3$ propose significant relationship between organizational trust and work engagement, and the analysis suggests that organizational trust has a significant and positive relationship with all work engagements' dimensions i.e. vigor, dedication and absorption. In conclusion, $\mathrm{H} 1, \mathrm{H} 2$ and $\mathrm{H} 3$ are supported. These findings are similar to those found in previous research by (Schaufeli \& Bakker, 2004); (Ibrahim \& Al Falasi, 2014); (Febriansyah et al., 2018).

The next hypotheses H4, H5 and H6 propose that there is a moderation effect of perceived stress on the relationship between organizational trust and work engagement dimensions i.e. vigor, dedication and absorption. The result suggests that perceived stress moderates the relationship between all the dimensions' vigor and absorption, and doesn't moderate the relationship of organizational trust with dedication. As a result, H5 is rejected while hypotheses $\mathrm{H} 4$ and $\mathrm{H} 6$ are accepted. These findings are similar to those found in a previous study by (Bhui, Dinos, Galant-Miecznikowska, de Jongh, et al., 2016); (Bashir\& Ramay, 2010); (Dawley et al., 2010). In conclusion, H4 and H6 are supported and H5 is not supported.

\section{Conclusion}

This article has utilized Social Exchange Theory to examine the relationships between organizational trust, perceived stress and work engagements in ministries in the West bank of Palestine. This study has demonstrated how organizational trust relates to work engagements and has also revealed that the organizational trust has significantly and positively contributed to work engagement. Additionally, this study shows that perceived stress has a moderating effect on the relationship between organizational trust and work engagement. 


\section{Mll Macrothink}

International Journal of Human Resource Studies ISSN 2162-3058 2021, Vol. 11, No. 2

My article works toward contributing to a better and deeper understanding of the concept of organizational trust in the workplace in Palestine, since empirical evidence has been tested to prove the relationships between the variables involved while also investigating the moderating effect of perceived stress on the relationship between organizational trust and work engagement. The findings show that organizational trust is significant in engaging employees in Palestinian ministries in order to survive and provide services in the public sector in Palestine.

There are limitations to the present study. Firstly, this study uses the self-reported questionnaire, which means that respondents are expected to give their responses to the posted questions without any mediation from the researcher. Secondly, present research development could be improved with the implementation of qualitative or multilevel research design. As a consequence, it is suggested that quantitative research, supported by exploratory research techniques such as interviews, is vital since the mixed approach has not yet been conducted in Palestine.

Future studies should intend to discover new findings and contributions in different areas of organizational trust, perceived stress, and work engagement. The scope can be further expanded to examine public sector organizations in Palestine

\section{Acknowledgments}

I would like to acknowledge AP Dr. Hazril Izwar Ibrahim at the School of Management at USM for his contribution in various facets of this article, especially his comments on the statistical analysis on the questionnaires.

\section{References}

Albrecht, S. L., Bakker, A. B., Gruman, J. A., Macey, W. H., \& Saks, A. M. (2015). Employee engagement, human resource management practices and competitive advantage: An integrated approach. In Journal of Organizational Effectiveness (Vol. 2, Issue 1, pp. 7-35). Emerald Group Publishing Ltd. https://doi.org/10.1108/JOEPP-08-2014-0042

BASHIR, U., \& Ramay, M. I. (2010). Impact Of Stress On Employees Job Performance A Study On Banking Sector Of Pakistan. International Journal of Marketing Studies, 2(1). https://doi.org/10.5539/ijms.v2n1p122

Bharanitharan, K., Chen, Z. X., Bahmannia, S., \& Lowe, K. B. (2018). Is Leader Humility a Friend or Foe, or Both? An Attachment Theory Lens on Leader Humility and Its Contradictory Outcomes. Journal of Business Ethics. https://doi.org/10.1007/s10551-018-3925-Z

Bhui, K., Dinos, S., Galant-Miecznikowska, M., de Jongh, B., \& Stansfeld, S. (2016). Perceptions of work stress causes and effective interventions in employees working in public, private and non-governmental organisations: a qualitative study. BJPsych Bulletin, 40(6), 318-325. https://doi.org/10.1192/pb.bp.115.050823

Bhui, K., Dinos, S., Galant-Miecznikowska, M., De Jongh, B., \& Stansfeld, S. (2016). 


\section{Macrothink Institute ${ }^{\mathrm{TM}}$}

International Journal of Human Resource Studies ISSN 2162-3058 2021, Vol. 11, No. 2

Perceptions of work stress causes and effective interventions in employees working in public, private and non-governmental organisations: A qualitative study. Psychiatrist, 40(6), 318-325. https://doi.org/10.1192/pb.bp.115.050823

Bradley, J. R., \& Cartwright, S. (2002). Social support, job stress, health, and job satisfaction among nurses in the United Kingdom. International Journal of Stress Management, 9(3), 163-182. https://doi.org/10.1023/A:1015567731248

Brower, H. H., Lester, S. W., Korsgaard, M. A., \& Dineen, B. R. (2009). A Closer Look at Trust Between Managers and Subordinates: Understanding the Effects of Both Trusting and Being Trusted on Subordinate Outcomes. Journal of Management, 35(2), 327-347. https://doi.org/10.1177/0149206307312511

Chen, J. C., Silverthorne, C., \& Hung, J. Y. (2006). Organization communication, job stress, organizational commitment, and job performance of accounting professionals in Taiwan and America. Leadership \& Organization Development Journal, 27(4), 242-249. https://doi.org/10.1108/01437730610666000

Dawley, D., Houghton, J., \& Bucklew, N. (2010). Perceived organizational support and turnover intention: The mediating effects of personal sacrifice and job fit. Journal of Social Psychology, 150(3), 238-257. https://doi.org/10.1080/00224540903365463

Duane, A., \& O'Reilly, P. (2017). A conceptual stages-of-growth model for managing a social media business profile. The Irish Journal of Management, 36(2), 78-98. https://doi.org/10.1515/ijm-2017-0015

Dunn, J. R., \& Schweitzer, M. E. (2005). Feeling and Believing: The Influence of Emotion on Trust. https://doi.org/10.1037/0022-3514.88.5.736

Febriansyah, H., Pringgabayu, D., Hidayanti, N., \& Citra Febrianti, F. (2018). Enhancing the employee engagement through the organizational climate (a study of school of business and management). In www.jbrmr.com A Journal of the Academy of Business and Retail Management (Vol. 12). ABRM. www.jbrmr.com

Ferrin, D. L., \& Dirks, K. T. (2002). Trust in Leadership: Meta-Analytic Findings and Implications for Research and Practice. Journal of Applied Psychology, 87(4), 611-628. https://doi.org/10.1037/0021-9010.87.4.611

Guinot, J., Chiva, R., \& Mallén, F. (2013). Organizational trust and performance: Is organizational learning capability a missing link? Journal of Management and Organization, 19(5), 559-582. https://doi.org/10.1017/jmo.2014.3

Guinot, J., Chiva, R., \& Roca-Puig, V. (2014). Interpersonal trust, stress and satisfaction at work: An empirical study. Personnel Review, 43(1), 96-115. https://doi.org/10.1108/PR-02-2012-0043

Gülbahar, B. (2017). The Relationship between Work Engagement and Organizational Trust: A Study of Elementary School Teachers in Turkey. Journal of Education and Training Studies, 5(2). https://doi.org/10.11114/jets.v5i2.2052 
Hassan, M., Toylan, N. V., Semerciöz, F., \& Aksel, I. (2012). Interpersonal Trust and Its Role in Organizations. International Business Research, 5(8). https://doi.org/10.5539/ibr.v5n8p33

Henseler, J., Ringle, C. M., \& Sinkovics, R. R. (2009). The use of partial least squares path modeling in international marketing. Advances in International Marketing, 20, 277-319. https://doi.org/10.1108/S1474-7979(2009)0000020014

Hsu, C.-W., Yin, C.-P., \& Huang, L.-T. (2017). Understanding Exchangers' Attitudes and Intentions to Engage in Internet Bartering Based on Social Exchange Theory (SET) and the Theory of Reasoned Action (TRA). 12(2). https://doi.org/10.6702/ijbi.2017.12.2.3

Ibrahim, M., \& Al Falasi, S. (2014). Employee loyalty and engagement in uae public sector. Employee Relations, 36(5), 562-582. https://doi.org/10.1108/ER-07-2013-0098

JONG, B. A. DE, \& ELFRING, T. (2010). HOW DOES TRUST AFFECT THE PERFORMANCE OF ONGOING TEAMS? THE MEDIATING ROLE OF REFLEXIVITY, MONITORING, AND EFFORT. In The Academy of Management Journal (Vol. 53, pp. 535-549). Academy of Management. https://doi.org/10.2307/25684335

Jouda, A. A., Norulkamar, U., Ahmad, U., \& Abed Dahleez, K. (2016). International Review of Management and Marketing The Impact of Human Resource Management Practices on Employees Performance: The Case of Islamic University of Gaza in Palestine. International Review of Management and Marketing, 6(4), 1080-1088. http:www.econjournals.com

Kahn, W. A. (1990). Psychological Conditions of Personal Engagement and Disengagement at Work. Academy of Management Journal, 33(4), 692-724. https://doi.org/10.5465/256287

Kahn, W. A. (1992). To Be Fully There: Psychological Presence at Work. Human Relations, 45(4), 321-349. https://doi.org/10.1177/001872679204500402

Khoury, G., \& Analoui, F. (2010a). How Palestinian managers cope with stress. Journal of Management Development, 29(3), 282-291. https://doi.org/10.1108/02621711011025795

Khoury, G., \& Analoui, F. (2010b). How Palestinian managers cope with stress. Journal of Management Development, 29(3), 282-291. https://doi.org/10.1108/02621711011025795

Kramer, R. M. (Roderick M., \& Tyler, T. R. (1996). Trust in organizations : frontiers of theory and research. Sage Publications.

Kular, S., Gatenby, M., Rees, C., Soane, E., Truss, K., \& Business School, K. (2008). Employee Engagement: A Literature Review. https://eprints.kingston.ac.uk/4192/1/19wempen.pdf

Lawless, M. H., Harrison, K. A., Grandits, G. A., Eberly, L. E., \& Allen, S. S. (2015). Perceived stress and smoking-related behaviors and symptomatology in male and female smokers. Addictive Behaviors, 51, 80-83. https://doi.org/10.1016/j.addbeh.2015.07.011

May, D. R., Gilson, R. L., \& Harter, L. M. (2004). The psychological conditions of meaningfulness, safety and availability and the engagement of the human spirit at work. Journal of Occupational and Organizational Psychology, 77(1), 11-37. 
https://doi.org/10.1348/096317904322915892

Mayer, R. C., Davis, J. H., \& Schoorman, F. D. (1995). An Integrative Model of Organizational Trust. The Academy of Management Review, 20(3), 709. https://doi.org/10.2307/258792

Mayer, R. C., \& Gavin, M. B. (2005). Trust in Management and Performance: Who Minds the Shop while the Employees Watch the Boss? In The Academy of Management Journal (Vol. 48, pp. 874-888). Academy of Management. https://doi.org/10.2307/20159703

Na'eim Ajis, M., Faizzah, N., \& Dollah, D. (2009). Relationship between Occupational Stress, Emotional Intelligence and Job Performance: An Empirical Study in Malaysia. https://www.researchgate.net/publication/46567577

Pierce, J. L., \& Gardner, D. G. (2004). Self-Esteem Within the Work and Organizational Context: A Review of the Organization-Based Self-Esteem Literature. Journal of Management, 30(5), 591-622. https://doi.org/10.1016/j.jm.2003.10.001

Rhee, K. Y. (2010). Different effects of workers' trust on work stress, perceived stress, stress reaction, and job satisfaction between Korean and Japanese workers. Safety and Health at Work, 1(1), 87-97. https://doi.org/10.5491/SHAW.2010.1.1.87

Safadi, N. S., Easton, S. D., Wang, Y., Hasson, R. G., \& Crea, T. M. (2019). Life and Job Satisfaction Among Public-Sector Social Workers in the occupied Palestinian Territory. Human Service Organizations: Management, Leadership \& Governance, 43(1), 41-53. https://doi.org/10.1080/23303131.2018.1564714

Schaufeli, W. B., \& Bakker, A. B. (2004). Job demands, job resources, and their relationship with burnout and engagement: A multi-sample study. Journal of Organizational Behavior, 25(3), 293-315. https://doi.org/10.1002/job.248

Schaufeli, W. B., Bakker, A. B., \& Salanova, M. (2006). The Measurement of Work Engagement With a Short Questionnaire. Educational and Psychological Measurement, 66(4), 701-716. https://doi.org/10.1177/0013164405282471

Tschannen-Moran, M., \& Hoy, W. (1998). Trust in schools: A conceptual and empirical analysis. Journal of Educational Administration, 36(4), 334-352. https://doi.org/10.1108/09578239810211518

Vineburgh, J. H. (2010). A study of organizational trust and related variables among faculty members at HBCUs. https://doi.org/10.17077/etd.iet9btjl

Wiegner, L., Hange, D., Björkelund, C., \& Ahlborg, G. (2015). Prevalence of perceived stress and associations to symptoms of exhaustion, depression and anxiety in a working age population seeking primary care - an observational study. BMC Family Practice, 16(1), 38. https://doi.org/10.1186/s12875-015-0252-7

Wong, J. D., Seltzer, M. M., Greenberg, J. S., Hong, J., Almeida, D. M., \& Coe, C. L. (2012). Stressful life events and daily stressors affect awakening cortisol level in midlife mothers of 


\section{Macrothink}

International Journal of Human Resource Studies

ISSN 2162-3058 2021, Vol. 11, No. 2

individuals with autism spectrum disorders. Aging and Mental Health, 16(8), 939-949. https://doi.org/10.1080/13607863.2012.688191

Yener, M., Yaldiran, M., \& Ergun, S. (2012). The Effect of Ethical Climate on Work Engagement. Procedia - Social and Behavioral Sciences, 58, 724-733. https://doi.org/10.1016/J.SBSPRO.2012.09.1050

\section{Copyright Disclaimer}

Copyright for this article is retained by the author(s), with first publication rights granted to the journal.

This is an open-access article distributed under the terms and conditions of the Creative Commons Attribution license (http://creativecommons.org/licenses/by/4.0/). 